\title{
Influence of dietary artemisinin supplementation on productive performance and haematological parameters of broiler chickens
}

\section{Loredana Maria Pop ${ }^{1}$, Laura Cristina Ştefănuț ${ }^{*}$, Alexandru Flaviu Tăbăran ${ }^{3}$, Anamaria loana Paştiu ${ }^{1}$, Zsuzsa Kalmár ${ }^{1}$, Cristian Alexandru Magdaş ${ }^{1}$, Viorica Mircean ${ }^{1}$, Adriana Györke ${ }^{1}$}

\footnotetext{
${ }^{1}$ University of Agricultural Sciences and Veterinary Medicine Cluj-Napoca, Faculty of Veterinary Medicine, Department of Parasitology and Parasitic Diseases, Cluj-Napoca, Romania.

${ }^{2}$ University of Agricultural Sciences and Veterinary Medicine Cluj-Napoca, Faculty of Veterinary Medicine, Department of Animal Physiology, Cluj-Napoca, Romania.

${ }^{3}$ University of Agricultural Sciences and Veterinary Medicine Cluj-Napoca, Faculty of Veterinary Medicine, Department of Pathology, Cluj-Napoca, Romania.
}

ABSTRACT - In the present study, we aimed to assess the toxicity of artemisinin on the haematological system and its effect on the productive performance of broiler chickens. Eighteen-day-old chickens were randomly divided into four groups of 30 chickens (three replicates of 10 broilers/group): control group and three experimental groups: ART5 - diet with 5 ppm of artemisinin; ART50 - diet with 50 ppm of artemisinin; and ART500 - diet with 500 ppm of artemisinin. Artemisinin enhanced the productive performances of broiler chickens at the lowest concentration (5 ppm), but at the highest concentration (500 ppm), it negatively affected weight gain and the feed conversion ratio. The performance characteristics of the chickens whose diets were supplemented with $50 \mathrm{ppm}$ artemisinin were similar to those of the control group. Additionally, $5 \mathrm{ppm}$ artemisinin in feed did not significantly affect the haematological parameters of the chickens, but 50 and 500 ppm artemisinin induced a gradual decline of the total leukocytes, lymphopenia, monocytosis, and eosinopenia, and the highest concentration caused anaemia. Artemisinin at a low concentration could be used as a feed additive in the poultry industry to improve organic broiler production performance with no serious side effects.

Key Words: animal nutrition, growth promoter, toxicity

\section{Introduction}

Artemisinin is a sesquiterpene lactone isolated from the herb Artemisia annua, which has been used with success for many centuries in traditional medicine to treat fever and jaundice and to heal wounds, eye infections, and skin diseases. The effects of artemisinin have been studied in many diseases, such as cancer and infectious or parasitic diseases, and artemisinin is used as a combination therapy against drug-resistant malaria (Naeem et al., 2014; Sadiq et al., 2014).

Different researchers have studied the effects of artemisinin and A. annua on chicken coccidiosis

Received: June 3, 2016

Accepted: October 31, 2016

*Corresponding author: clcernea@yahoo.com

http://dx.doi.org/10.1590/S1806-92902017000200008

How to cite: Pop, L. M.; Ştefănuț, L. C.; Tăbăran, A. F.; Paştiu, A. I.; Kalmár, Z.; Magdaş, C. A.; Mircean, V. and Györke, A. 2017. Influence of dietary artemisinin supplementation on productive performance and haematological parameters of broiler chickens. Revista Brasileira de Zootecnia 46(2):130-137.

Copyright (C) 2017 Sociedade Brasileira de Zootecnia. This is an Open Access article distributed under the terms of the Creative Commons Attribution License (http://creativecommons.org/licenses/by/4.0/), which permits unrestricted use, distribution, and reproduction in any medium, provided the original work is properly cited.
(Allen et al., 1997;1998; Youn, 2001; Arab et al., 2006; del Cacho, 2010; de Almeida, 2012; Drăgan et al., 2014). Coccidiosis is an economically devastating disease for the poultry industry. The development of drug resistance to all known anticoccidial drugs and consumer concerns regarding drug residues have increased the interest of the scientific community in searching for alternative means of coccidiosis prevention. Botanicals, natural feedstuffs, and artemisinin are intensively studied compounds (Chapman, 1997; Allen and Fetterer, 2002, Abbas, 2012a; Abbas, 2012b).

Despite the extensive research on using artemisinin in coccidiosis control, its effect on chickens has not been sufficiently investigated. Arab et al. (2009) showed that chickens treated with a single oral dose of artemisinin exhibited neurological signs, liver, kidney, and brain degeneration, especially at very high dosages, and presented a dose-dependent reduced feed intake. Shahbazfar et al. (2011) showed that after chronic intake of artemisinin, the chickens exhibited anaemia, dose-dependent decreases in haematocrit and red blood cells, and mild lesions in liver, kidney, and brain. The authors concluded that at therapeutic dosages, artemisinin causes no serious side effects.

Although artemisinin has been proven to be safe in chickens at therapeutic dosages, the negative effect on the 
haematological system and the effect on the productive performance of chickens needs further investigation.

\section{Material and Methods}

Ross 308 broiler chickens were purchased at one day of age and were housed in metal cages. Feed and water were provided ad libitum and the lighting programme was continuous. From 1-18 days of age, the chickens received standard broiler starter feed without the addition of anticoccidials (Table 1).

Veterinary conditions regarding the protection of the animals used in this research were complied with all national and EU standards and legislation. All experiments were approved by the Research Bioethics Commission of UASMV Cluj-Napoca (case no. 4/19.09.2013).

Artemisinin powder (min. 98\% purity) was purchased from Intatrade Chemicals $\mathrm{GmbH}$, Germany, and was introduced in the feed in concentrations of 5,50 , and $500 \mathrm{ppm}$

Table 1 - Composition of basic diets of broiler chickens at 1-46 days of age

\begin{tabular}{|c|c|c|}
\hline & $\begin{array}{c}\text { Starter } \\
\text { (1-17 days) }\end{array}$ & $\begin{array}{c}\text { Grower } \\
\text { (18-46 days) }\end{array}$ \\
\hline Dry matter $(\mathrm{g} / \mathrm{kg})$ & 879.0 & 885.7 \\
\hline Crude protein $(\mathrm{g} / \mathrm{kg})$ & 199.6 & 175.0 \\
\hline Crude fat $(\mathrm{g} / \mathrm{kg})$ & 28.4 & 45.7 \\
\hline Crude cellulose $(\mathrm{g} / \mathrm{kg})$ & 49.9 & 33.3 \\
\hline Ash (g/kg) & - & 8.8 \\
\hline Metabolisable energy $(\mathrm{Mj} / \mathrm{kg})$ & 11.65 & 12.60 \\
\hline Methionine (g/kg) & 3.8 & 4.4 \\
\hline Threonine $(\mathrm{g} / \mathrm{kg})$ & - & 6.3 \\
\hline Methionine + cysteine $(\mathrm{g} / \mathrm{kg})$ & 7.1 & 8.0 \\
\hline Tryptophan (g/kg) & 2.3 & 1.9 \\
\hline Lysine $(\mathrm{g} / \mathrm{kg})$ & 9.7 & 11.5 \\
\hline $\mathrm{Ca}(\mathrm{g} / \mathrm{kg})$ & 9.6 & 10.0 \\
\hline $\mathrm{P}(\mathrm{g} / \mathrm{kg})$ & 6.8 & 7.0 \\
\hline $\mathrm{Na}(\mathrm{g} / \mathrm{kg})$ & 1.2 & 1.5 \\
\hline $\mathrm{Zn}(\mathrm{mg} / \mathrm{kg})$ & 50.36 & 70.13 \\
\hline $\mathrm{Cu}(\mathrm{mg} / \mathrm{kg})$ & 8.63 & 12.02 \\
\hline $\mathrm{Fe}(\mathrm{mg} / \mathrm{kg})$ & 43.16 & 60.11 \\
\hline $\mathrm{Mn}(\mathrm{mg} / \mathrm{kg})$ & 71.94 & 100.19 \\
\hline $\mathrm{I}(\mathrm{mg} / \mathrm{kg})$ & 0.72 & 1.00 \\
\hline $\mathrm{Se}(\mathrm{mg} / \mathrm{kg})$ & 0.14 & 0.20 \\
\hline Betaine (mg/kg) & - & 200.60 \\
\hline Vitamin A (IU/kg) & 10152.00 & 12096.00 \\
\hline Vitamin D3 (IU/kg) & 2538.00 & 3024.00 \\
\hline Vitamin E (mg/kg) & 33.84 & 40.32 \\
\hline Vitamin K3 (mg/kg) & 2.54 & 3.02 \\
\hline Vitamin B1 (mg/kg) & 2.50 & 3.02 \\
\hline Vitamin B2 (mg/kg) & 5.92 & 7.06 \\
\hline Ca d-pantothenate $(\mathrm{mg} / \mathrm{kg})$ & 10.15 & 12.10 \\
\hline Vitamin B6 (mg/kg) & 4.23 & 5.04 \\
\hline Vitamin B12 (mg/kg) & 0.02 & 0.03 \\
\hline Biotin (mg/kg) & 0.10 & 0.12 \\
\hline Niacin $(\mathrm{mg} / \mathrm{kg})$ & 33.84 & 40.32 \\
\hline Folic acid (mg/kg) & 0.85 & 1.01 \\
\hline Choline (mg/kg) & 398.40 & - \\
\hline Antioxidant (mg/kg) & 128.00 & 128.00 \\
\hline
\end{tabular}

(5, 50, and $500 \mathrm{mg}$ artemisinin $/ \mathrm{kg}$ feed), according to the dosages used in a previously published manuscript of the anticoccidial effect of artemisinin (Pop et al., 2015).

At 18 days old, broilers were divided into four experimental groups of 30 chickens each, with three replicates of 10 individually marked chickens. On the same day (day 0 of the experiment), the experimental feed was introduced into their diet for 28 days (until the age of 46 days). The groups were as follows: a control group, which received standard broiler grower feed without the addition of anticoccidials (Table 1); and three experimental groups: ART5 - diet with 5 ppm of artemisinin; ART50 diet with $50 \mathrm{ppm}$ of artemisinin; and ART500 - diet with $500 \mathrm{ppm}$ of artemisinin. On day 0 and after 14 and 28 days of continuous administration of experimental feed, blood samples were aseptically collected from the ulnar vein of each chicken from the first replicate into heparin-containing tubes $(50 \mathrm{IU} / \mathrm{mL})$; a- $2.0 \mathrm{~mL}$ syringe and $23 \mathrm{G}$ needle were used for the collections.

Blood samples were tested for red blood cells (RBC) count, haemoglobin concentration, packed cell volume (PCV), the total and differential white blood cells (WBC) counts, and the values of derived erythrocyte constants: mean corpuscular volume (MCV), mean corpuscular haemoglobin $(\mathrm{MCH})$, and the mean corpuscular haemoglobin concentration (MCHC).

The count of the total number of RBC and WBC was carried out manually by the haemocytometer method using Natt-Herrick modified by Prochaska dilution liquid (Ognean and Cernea, 2011).

The concentration of haemoglobin was determined by the spectrophotometer method (ELISA Bio-Rad 1100 microplate reader); the absorbance at $540 \mathrm{~nm}$ was measured after adding $4 \%$ ammonia solution to the blood samples.

The PCV was established using the microhaematocrit method. Briefly, capillary tubes were filled $2 / 3$ with anticoagulated blood, the unfilled ends were sealed with clay, and they were centrifuged at $12,000 \mathrm{rpm}$ for $5 \mathrm{~min}$. The PCV values were determined with the aid of a microhaematocrit reader.

The MCV, MCH, and MCHC were calculated using the following formulas:

$$
\begin{gathered}
\operatorname{MCV}\left(\mu \mathrm{m}^{3}\right)=[\mathrm{PCV} \times 10] / \mathrm{RBC} \\
\mathrm{MCH}(\mathrm{pg})=[\mathrm{Hb} \times 10] / \mathrm{RBC} \\
\mathrm{MCHC}(\mathrm{g} / \mathrm{dL})=[\mathrm{Hb} \times 100] / \mathrm{PCV}
\end{gathered}
$$

Differential WBC counts were performed by the microscopic examination of blood smears; 100 successive $\mathrm{WBC} /$ sample were counted and identified, and the results were reported as the percentages of different WBC (Samour, 2006). 
At the end of the experiment, the chickens were euthanatized by cervical dislocation and chicken necropsies were performed.

Bone marrow samples were collected from the chickens in the first replicate for both histological and cytological evaluations (Elmore, 2006). For the histopathological examination, the proximal tibiotarsus (Campbell, 1994) was bilaterally harvested, cleaned of connective tissue and skin, and trimmed longitudinally into small pieces (approximately $1 \times 1 \mathrm{~cm}$ with $0.2-\mathrm{cm}$ thickness). After $72 \mathrm{~h}$ of fixation in 10\% neutral-buffered formalin, the samples were decalcified for three weeks in a 1:1 mixture of $8 \%$ formic acid and $8 \%$ hydrochloric acid (Prophet, 1992). When decalcification was completed, the tissues were dehydrated using an isopropyl alcohol gradient (70\%, $90 \%, 95 \%$, and $100 \%$ ), clarified in xylene and embedded in paraffin wax of high-melting temperature following a routine processing protocol (Prophet et al., 1992). After solidification, the paraffin blocks were trimmed and kept at room temperature until use. Tissue sections were cut from each paraffin block at 2-3- $\mu \mathrm{m}$ thickness with a rotary microtome (Leica RM 2125) and were stored overnight at $37{ }^{\circ} \mathrm{C}$ on a thermostatically controlled slide warmer. Tissue sections were routinely stained with haematoxylin and eosin (H\&E) and examined using an Olympus BX41 microscope.

During histopathological examination, the proportions of granulocytic to erythroid cells (or Myeloid to Erythroid ratio) were assessed (Wakenell, 2010; Reagan et al., 2011).

The bone marrow smears were produced using touch imprints and the push-slide technique with sectioned proximal tibiotarsus before it was trimmed for histopathology. After fixation, the smears were stained using the Wright-Giemsa technique.
Bright field microscopy was performed using a 3.2megapixel resolution Olympus UC30 Digital Camera and processed with the Olympus Stream Basic image analysis software (Olympus Stream Basic Package).

The amount of consumed feed was monitored daily per cage and the chickens were weighed individually on days 0,14 , and 28 of the experiment to determine the weight gain, feed intake, and feed conversion ratio.

Statistical analysis was performed using Medcalc software, version 15.8. The normal distribution of the data was verified by Shapiro-Wilk test and in the case of normally distributed data, independent samples T-test was performed, which consisted of an $\mathrm{F}$ test for equal variances; depending on the variance, T-test (equal variances) or Welch-test (unequal variances) was used. Mann-Whitney tests were used for data that were not normally distributed. The statistical interpretation of the histopathological and cytological data was performed by ANOVA test using the Origin 8.5 software. Differences were considered significant at a $\mathrm{P}$-value less than or equal to 0.05 .

\section{Results}

At the first blood sample collection (day 0), the number of erythrocytes was higher in the groups treated with 5 and $500 \mathrm{ppm}$ artemisinin compared with that of the control group $(\mathrm{P} \leq 0.01)$. At the second collection, the total number of erythrocytes increased significantly in all experimental groups, but there were no significant differences between groups. At the third blood sample collection, the RBC count had similar values between the control and ART5 groups; the ART50 group had fewer erythrocytes compared with the control group ( $\mathrm{P}=0.03)$, and the chickens from ART 500

Table 2 - Effect of different concentrations of artemisinin on erythrogram parameters of broiler chickens compared with control group

\begin{tabular}{|c|c|c|c|c|c|c|c|}
\hline Blood sampling & Group & $\mathrm{RBC}\left(\times 10^{12} / \mathrm{L}\right)$ & $\mathrm{PCV}(\%)$ & $\mathrm{Hb}(\mathrm{g} / \mathrm{dL})$ & $\operatorname{MCV}\left(\mu \mathrm{m}^{3}\right)$ & $\mathrm{MCH}(\mathrm{pg})$ & $\mathrm{MCHC}(\mathrm{g} / \mathrm{dL})$ \\
\hline \multirow{4}{*}{ First } & Control & $1.88 \pm 0.70 \mathrm{a}$ & $27.3 \pm 0.67 b$ & $5.12 \pm 0.15 a$ & $155.99 \pm 12.96 a$ & $28.86 \pm 2.28 \mathrm{a}$ & $18.71 \pm 0.67 \mathrm{a}$ \\
\hline & ART5 & $3.37 \pm 0.36 b$ & $29.7 \pm 0.58 \mathrm{a}$ & $5.18 \pm 0.15 \mathrm{a}$ & $91.54 \pm 9.14 b$ & $17.03 \pm 2.00 \mathrm{~b}$ & $18.67 \pm 0.84 \mathrm{a}$ \\
\hline & ART50 & $2.06 \pm 0.36 \mathrm{ac}$ & $27.5 \pm 0.70 b$ & $5.37 \pm 0.33 \mathrm{a}$ & $102.32 \pm 25.87 \mathrm{ab}$ & $20.32 \pm 5.65 b$ & $19.71 \pm 1.23 \mathrm{ab}$ \\
\hline & ART500 & $3.04 \pm 0.44 b c$ & $27.9 \pm 0.64 \mathrm{ab}$ & $6.28 \pm 0.23 b$ & $114.51 \pm 15.22 b$ & $24.23 \pm 3.49 \mathrm{ab}$ & $21.08 \pm 0.68 \mathrm{~b}$ \\
\hline \multirow{4}{*}{ Second } & Control & $5.94 \pm 1.11 \mathrm{a}$ & $28.6 \pm 0.55 \mathrm{ab}$ & $5.14 \pm 0.26 \mathrm{a}$ & $62.08 \pm 9.75 \mathrm{a}$ & $11.40 \pm 2.02 \mathrm{a}$ & $17.94 \pm 0.86 \mathrm{a}$ \\
\hline & ART5 & $4.94 \pm 0.77 \mathrm{a}$ & $29.0 \pm 0.50 \mathrm{a}$ & $6.51 \pm 0.50 \mathrm{~b}$ & $72.43 \pm 9.91 \mathrm{a}$ & $16.03 \pm 2.47 \mathrm{a}$ & $22.49 \pm 1.68 \mathrm{ab}$ \\
\hline & ART50 & $4.55 \pm 0.99 a$ & $26.9 \pm 0.85 b$ & $5.85 \pm 0.57 \mathrm{ab}$ & $96.01 \pm 22.15 \mathrm{a}$ & $19.80 \pm 4.16 \mathrm{a}$ & $21.66 \pm 1.79 \mathrm{ab}$ \\
\hline & ART500 & $5.04 \pm 1.05 \mathrm{a}$ & $28.7 \pm 0.68 \mathrm{ab}$ & $6.63 \pm 0.54 b$ & $81.58 \pm 14.24 \mathrm{a}$ & $18.78 \pm 3.83 \mathrm{a}$ & $23.20 \pm 1.89 b$ \\
\hline \multirow{4}{*}{ Third } & Control & $3.76 \pm 0.25 \mathrm{a}$ & $26.0 \pm 1.12 \mathrm{a}$ & $5.46 \pm 0.36 \mathrm{a}$ & $72.48 \pm 5.11 \mathrm{a}$ & $15.26 \pm 1.63 \mathrm{a}$ & $20.87 \pm 1.46 \mathrm{a}$ \\
\hline & ART5 & $3.35 \pm 0.32 \mathrm{ab}$ & $25.8 \pm 0.70 \mathrm{a}$ & $4.68 \pm 0.26 \mathrm{a}$ & $84.13 \pm 9.11 \mathrm{ab}$ & $15.86 \pm 2.53 \mathrm{ab}$ & $18.22 \pm 1.08 \mathrm{a}$ \\
\hline & ART50 & $3.13 \pm 0.23 b$ & $25.2 \pm 0.80 \mathrm{a}$ & $4.51 \pm 0.39 a$ & $83.90 \pm 5.63 a$ & $14.91 \pm 1.55 \mathrm{ab}$ & $18.03 \pm 1.62 \mathrm{a}$ \\
\hline & ART500 & $2.23 \pm 0.14 \mathrm{c}$ & $23.3 \pm 1.12 \mathrm{a}$ & $4.28 \pm 0.71 \mathrm{a}$ & $106.49 \pm 6.20 \mathrm{~b}$ & $20.61 \pm 3.49 b$ & $18.67 \pm 3.27 \mathrm{a}$ \\
\hline
\end{tabular}

RBC - red blood cells; PCV - packed cell volume; Hb - haemoglobin; MCV - mean corpuscular volume; MCH - mean corpuscular haemoglobin; MCHC - mean corpuscular haemoglobin concentration; ART5 - diet with 5 ppm artemisinin; ART50 - diet with 50 ppm artemisinin; ART500 - diet with 500 ppm artemisinin.

Values with no common letters in a column and periods of blood sampling were significantly different $(\mathrm{P}<0.05)$.

Results are expressed as means \pm standard error of the mean. 
group had a very low number of erythrocytes $\left(2.23 \times 10^{12} / \mathrm{L}\right)$ (Table 2).

Before the administration of artemisinin, the ART5 group had a higher value of PCV than that of the control group $(\mathrm{P}=0.01)$. In day 14 of the experiment, all the groups had similar percentages of PCV. In correlation with the values recorded for the $\mathrm{RBC}$ counts, at 28 days after the administration of experimental feed, all the groups exhibited lower PCV values, and the chickens of the ART500 group had the lowest values compared with those of the control group ( $\mathrm{P}=0.1)$ (Table 2$)$.

At the first blood collection, the concentration of haemoglobin values were similar in all groups except the ART500 group, which had a higher haemoglobin concentration $(\mathrm{P}=0.0005)$. This trend persisted at the second blood sampling as well $(\mathrm{P}=0.02)$, but in the third collection, the ART500 group had a lower haemoglobin concentration compared with that of the control group $(\mathrm{P}=0.09)$ and also with those of the other two samplings $(\mathrm{P} \leq 0.02)$ (Table 2).

The value of MCV decreased significantly at the second sampling and slightly increased at the third blood collection in all experimental groups. In the first sampling, the chickens from all artemisinin-treated groups had a lower value of MCV compared with the control group and this difference was more significant in the ART5 and ART500 groups $(\mathrm{P} \leq 0.05)$. At the second sampling, the values recorded did not significantly differ among groups. At the final recording, the highest value was recorded for the ART500 group $\left(106.49 \mu \mathrm{m}^{3} ; \mathrm{P}=0.0008\right)$. The same trend was observed for $\mathrm{MCH}$. The $\mathrm{MCHC}$ values were similar in all groups, except for the ART500, which had a higher $\mathrm{MCHC}$ value at the first and second blood samplings $(\mathrm{P} \leq 0.02)$ (Table 2$)$.
At the first two blood samplings, the total number of WBC was higher in the experimental groups than in the control group and the only WBC values from the ART5 group at the first collection were significantly different $(\mathrm{P}=0.006)$. After 28 days of administration of artemisinin in the feed of chickens, the WBC values recorded for all experimental groups were lower than those for the control group $(\mathrm{P} \leq 0.4)$. In terms of dynamics, the control group had similar values at all three blood samplings, while in the groups treated with artemisinin, the total number of WBC was significantly decreased from the first sampling until the last $(\mathrm{P} \leq 0.05)$. The ART5 group had the most dramatic decrease of WBC $(\mathrm{P}<0.001)$, although the lowest value recorded was in the ART500 group after 28 days of experimental feed administration (Table 3 ).

Regarding the different types of leukocytes, the groups treated with 5 or $50 \mathrm{ppm}$ artemisinin had a progressive decrease in their heterophil percentage from the first to last blood sampling, with the lowest value recorded for the ART50 group $(17.4 \%)$ at the third blood collection $(\mathrm{P}=0.02)$. However, the heterophil percentage of the chickens that received $5 \mathrm{ppm}$ artemisinin in their feed was similar to that of the control group at the second and third samplings. The ART500 group had similar values of heterophil percentages at all three collections, but these values were only significantly lower than those recorded for the control group at the third blood sampling $(\mathrm{P}<0.05)$ (Table 3).

The percentage of lymphocytes was significantly decreased from the first blood sampling until the last sampling in all groups treated with artemisinin $(\mathrm{P} \leq 0.05)$. Although the control group had a lower percentage at the second collection, this reduction was recovered in the third blood sampling. The highest reduction in the lymphocyte

Table 3 - Effect of different concentrations of artemisinin on leukogram parameters of broiler chickens compared with control group

\begin{tabular}{|c|c|c|c|c|c|c|c|}
\hline \multirow{2}{*}{ Blood sampling } & \multirow{2}{*}{ Group } & \multirow{2}{*}{$\mathrm{WBC}\left(\times 10^{9} / \mathrm{L}\right)$} & \multicolumn{5}{|c|}{ Differential WBC (\%) } \\
\hline & & & Heterophils & Lymphocytes & Monocytes & Eosinophils & Basophils \\
\hline \multirow{4}{*}{ First } & Control & $13.9 \pm 1.03 \mathrm{a}$ & $24.6 \pm 4.20 \mathrm{a}$ & $40.5 \pm 4.81 \mathrm{a}$ & $20.8 \pm 3.93 a$ & $13.5 \pm 1.86 \mathrm{a}$ & $0.6 \pm 0.40 \mathrm{a}$ \\
\hline & ART5 & $22.3 \pm 2.32 b$ & $28 \pm 3.56 \mathrm{a}$ & $36.6 \pm 3.66 \mathrm{a}$ & $23.3 \pm 4.53 \mathrm{a}$ & $11.3 \pm 1.85 \mathrm{a}$ & $0.8 \pm 0.61 \mathrm{a}$ \\
\hline & ART50 & $15.7 \pm 1.43 \mathrm{ab}$ & $25.3 \pm 3.20 \mathrm{a}$ & $45.7 \pm 2.64 \mathrm{ab}$ & $14.7 \pm 1.77 \mathrm{a}$ & $13 \pm 1.51 \mathrm{a}$ & $1.3 \pm 0.65 \mathrm{a}$ \\
\hline & ART500 & $17.1 \pm 1.06 \mathrm{~b}$ & $19.9 \pm 3.34 \mathrm{a}$ & $52.3 \pm 2.89 \mathrm{~b}$ & $16.3 \pm 2.32 \mathrm{a}$ & $10.4 \pm 1.54 \mathrm{a}$ & $1.1 \pm 0.57 \mathrm{a}$ \\
\hline \multirow{2}{*}{ Second } & Control & $13.8 \pm 2.39 \mathrm{a}$ & $23.2 \pm 2.98 \mathrm{a}$ & $27.8 \pm 4.77 \mathrm{a}$ & $31.5 \pm 4.17 \mathrm{a}$ & $17.5 \pm 4.37 \mathrm{a}$ & $0 \mathrm{a}$ \\
\hline & ART500 & $15.5 \pm 1.74 \mathrm{a}$ & $21.5 \pm 3.06 \mathrm{a}$ & $25.7 \pm 4.67 \mathrm{a}$ & $30.1 \pm 2.76 \mathrm{a}$ & $22.7 \pm 2.86 \mathrm{a}$ & $0 \mathrm{a}$ \\
\hline \multirow{4}{*}{ Third } & Control & $13.0 \pm 1.45 \mathrm{a}$ & $22.0 \pm 1.18 \mathrm{a}$ & $38.38 \pm 1.95 \mathrm{a}$ & $12.5 \pm 2.07 \mathrm{a}$ & $26 \pm 2.23 \mathrm{a}$ & $1.13 \pm 0.40 \mathrm{a}$ \\
\hline & ART5 & $11.2 \pm 0.39 \mathrm{a}$ & $23.0 \pm 1.06 \mathrm{a}$ & $29.8 \pm 1.00 \mathrm{~b}$ & $23.9 \pm 1.00 \mathrm{~b}$ & $23.3 \pm 2.54 \mathrm{ab}$ & $\mathrm{Ob}$ \\
\hline & ART50 & $11.3 \pm 0.56 \mathrm{a}$ & $17.4 \pm 0.60 \mathrm{~b}$ & $30.8 \pm 1.44 b$ & $38.2 \pm 1.32 \mathrm{c}$ & $13.6 \pm 1.35 \mathrm{c}$ & $0 \mathrm{~b}$ \\
\hline & ART500 & $10.2 \pm 0.99 \mathrm{a}$ & $19.11 \pm 0.70 \mathrm{~b}$ & $25.33 \pm 1.69 \mathrm{c}$ & $38.89 \pm 1.26 \mathrm{c}$ & $16.67 \pm 1.41 b c$ & $\mathrm{Ob}$ \\
\hline
\end{tabular}

WBC - white blood cells; ART5 - diet with 5 ppm artemisinin; ART50 - diet with 50 ppm artemisinin; ART500 - diet with 500 ppm artemisinin.

Results are expressed as means \pm standard error of the mean. 
percentage was recorded for the ART500 group, but this group had a higher percentage of lymphocytes at the first blood sampling compared with the control group $(\mathrm{P}=0.05)$. After 28 days of artemisinin administration, the percentage of lymphocytes in the chickens from all experimental groups was significantly lower than that in the control group $(\mathrm{P} \leq 0.005)$ (Table 3$)$.

The percentage of monocytes in the control group was increased at the second blood sampling and was dramatically decreased at the third sampling. This aspect was also recorded in the chickens treated with $5 \mathrm{ppm}$ artemisinin, but in the third blood sampling, the percentage of monocytes in this group was significantly higher than that of the control group $(\mathrm{P}=0.0004)$. In the two other artemisinin-treated groups, the percentage of monocytes increased gradually from the first to the third blood sampling and had similar values, but these values were much higher than those of the control group at the third collection $(\mathrm{P} \leq 0.0005)$ (Table 3 ).

The eosinophil percentage in the chickens treated with 50 and $500 \mathrm{ppm}$ artemisinin was significantly lower than that of the control group at the third blood sampling $(\mathrm{P} \leq 0.002)$ (Table 2).
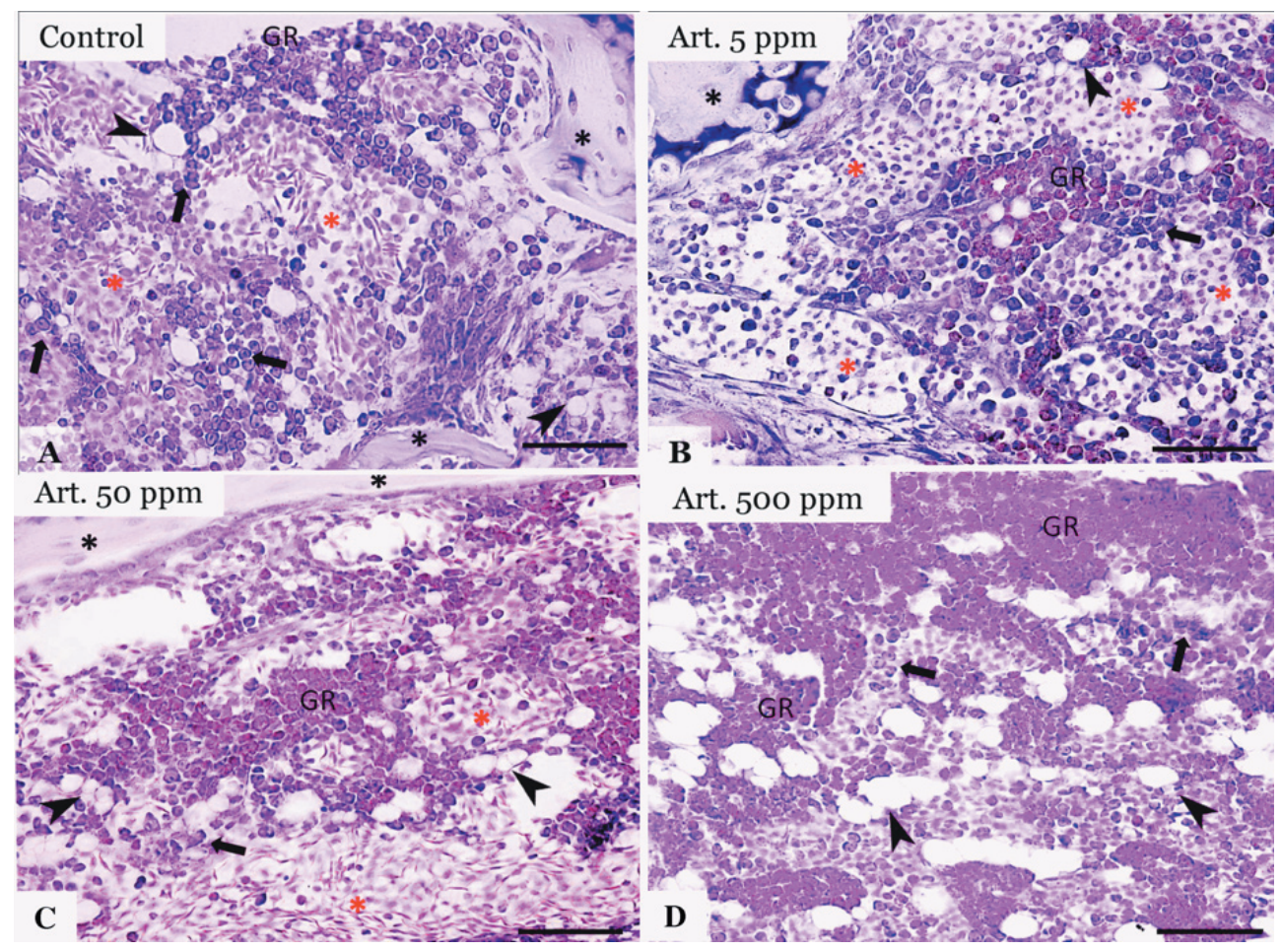

In all images, abundant venous sinuses (indicated by red asterisks) delineate islands and sheets of haematopoietic cells that are admixed in various proportions with mature adipocytes (indicated by arrow heads). A moderately increased number of myeloid precursors can be observed for the ART50 (image C) and ART500 (image D) groups compared with the control group (image A).

GR - myeloid cells (granulocytic/myeloid); arrows indicate cells from the erythroid cell line.

Black asterisks indicate the trabecular bone, lined by flattened or cuboidal osteoblasts and sparse osteoclasts.

H\&E stain, objective $x 40$. Scale bar $=75 \mu \mathrm{m}$

Figure 1 - Representative histological images of the bone marrow following chronic oral intake of 5,50 or $500 \mathrm{ppm}$ artemisinin compared with the control group. 
control group, but this difference was significant only at the second and third samplings ( $\mathrm{P} \leq 0.001)$. The ART50 group had values that were similar to those of the control group during the experiment. The chickens treated with $500 \mathrm{ppm}$ artemisinin had a lower feed intake compared with that of the control group at all the three samplings $(\mathrm{P} \leq 0.03)$ (Table 4).

In the first sampling recorded, the feed conversion ratio was superior for the group treated with $5 \mathrm{ppm}$ artemisinin $(P=0.0005)$, while the group treated with $500 \mathrm{ppm}$ artemisinin had an inefficient use of feed compared with that of the control group $(\mathrm{P}=0.02)$. In the period from 14-28 days, all the groups had similar values of FCR. For the total period of recording, the groups treated with $500 \mathrm{ppm}$ artemisinin had the worst FCR $(\mathrm{P}=0.2)$, while the chickens that received $5 \mathrm{ppm}$ artemisinin had a better FCR compared with that of the control group $(\mathrm{P}=0.1)$ (Table 4).

\section{Discussion}

The poultry industry has benefited from rapid development, mainly due to advances in genetics, nutrition, and health management. Diet formulations are especially important because they can increase broiler performances or can cause great economic losses in the meat industry (Alvarenga et al., 2015).
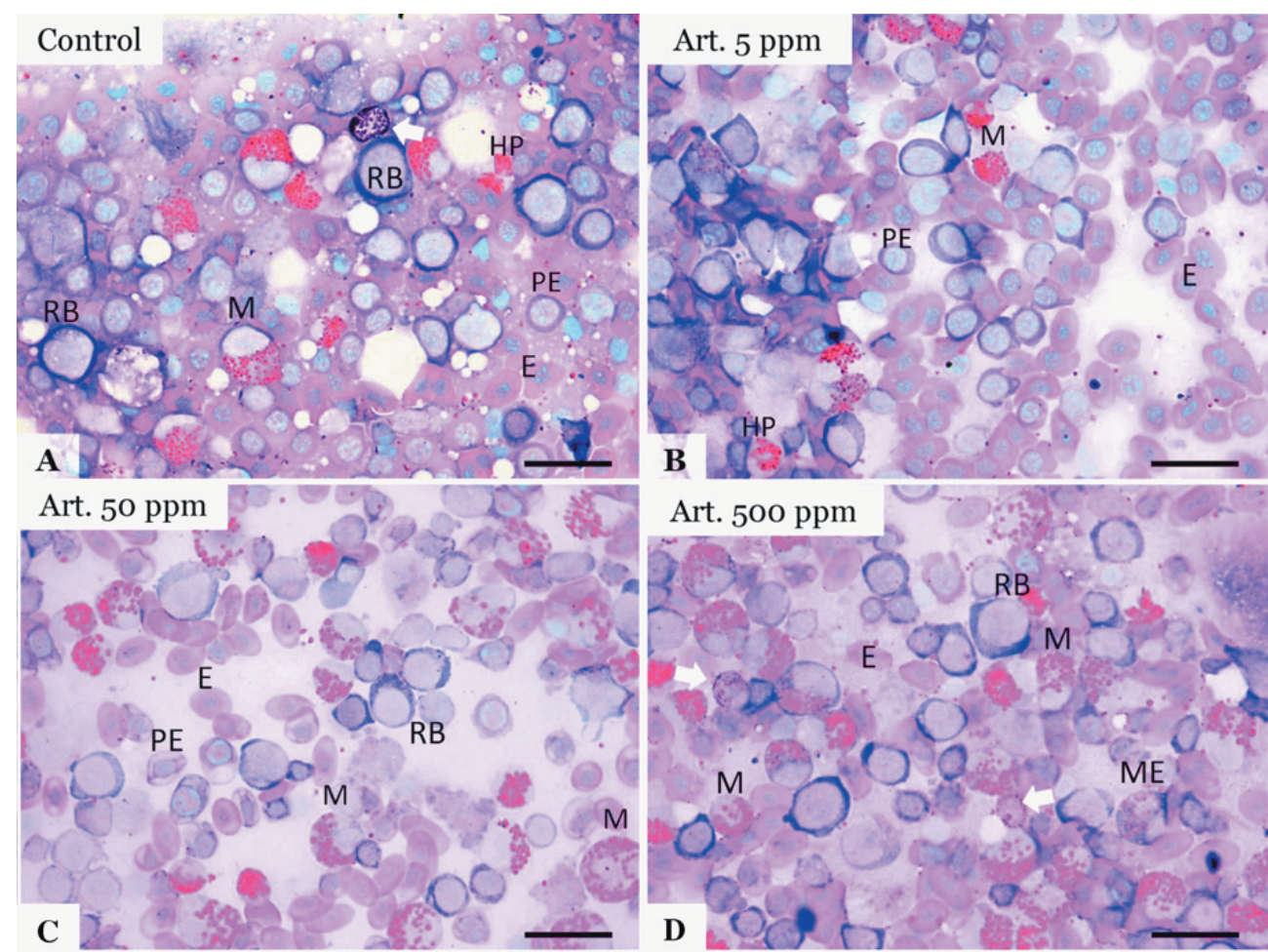

E - mature erythrocyte; PE - polychromatic rubricytes and erythrocytes; M - myelocyte; ME - eosinophilic myelocytes; RB - rubriblast; HP - heterophil. Wright-Giemsa stain, objective $\mathrm{x} 100$. Scale bar $=20 \mu \mathrm{m}$.

Figure 2 - Cytological images of bone marrow following the chronic oral intake of 5, 50, and 500 ppm artemisinin compared with the control group.

Table 4 - The effect of different concentrations of artemisinin on production performances of broiler chickens compared with control group

\begin{tabular}{|c|c|c|c|c|c|c|c|c|c|}
\hline \multirow{2}{*}{ Group } & \multicolumn{3}{|c|}{ Weight gain } & \multicolumn{3}{|c|}{ Feed intake } & \multicolumn{3}{|c|}{ Feed conversion ratio } \\
\hline & 0 -14 days & 14-28 days & 0-28 days & $0-14$ days & 14-28 days & $0-28$ days & 0-14 days & 14-28 days & $0-28$ days \\
\hline Control & $43.44 \pm 1.30 \mathrm{a}$ & $42.41 \pm 1.60 \mathrm{ab}$ & $42.92 \pm 1.26 \mathrm{a}$ & $114.52 \pm 0.04 \mathrm{a}$ & $124.41 \pm 0.12 \mathrm{a}$ & $119.47 \pm 0.07 \mathrm{ab}$ & $2.71 \pm 3.10 \mathrm{a}$ & $3.07 \pm 1.43 \mathrm{a}$ & $2.89 \pm 1.85 \mathrm{a}$ \\
\hline Art5 & $48.40 \pm 1.42 b$ & $46.71 \pm 1.59 \mathrm{a}$ & $47.56 \pm 1.28 \mathrm{a}$ & $117.35 \pm 0.03 b$ & $143.30 \pm 0.12 \mathrm{a}$ & $130.33 \pm 0.06 \mathrm{a}$ & $2.43 \pm 1.40 \mathrm{a}$ & $3.09 \pm 2.85 b$ & $2.75 \pm 1.47 \mathrm{~b}$ \\
\hline Art50 & $42.76 \pm 1.70 \mathrm{a}$ & $41.49 \pm 2.11 \mathrm{ab}$ & $42.33 \pm 1.64 a$ & $113.34 \pm 0.05 \mathrm{a}$ & $126.40 \pm 0.11 \mathrm{a}$ & $119.87 \pm 0.06 \mathrm{ab}$ & $2.66 \pm 1.88 \mathrm{a}$ & $3.12 \pm 4.02 \mathrm{a}$ & $2.88 \pm 2.59 a$ \\
\hline Art500 & $33.71 \pm 1.21 \mathrm{c}$ & $38.07 \pm 1.47 \mathrm{~b}$ & $35.89 \pm 1.16 \mathrm{a}$ & $98.13 \pm 0.11 \mathrm{c}$ & $111.48 \pm 0.12 \mathrm{a}$ & $104.81 \pm 0.11 b$ & $3.02 \pm 5.16 \mathrm{~b}$ & $3.07 \pm 4.52 \mathrm{c}$ & $3.04 \pm 4.38 \mathrm{c}$ \\
\hline
\end{tabular}

ART5 - diet with 5 ppm artemisinin; ART50 - diet with 50 ppm artemisinin; ART500 - diet with 500 ppm artemisinin.

Values with no common letter in a column are significantly different $(\mathrm{P}<0.05)$.

Results are expressed as means \pm standard error of the mean. 
Despite advances in drug development, broilers are still exposed to many infectious or parasitic diseases that produce losses with morbidity or even mortality. Searching for alternative substances for disease control, particularly natural products, is highly encouraged not only for solving the problem of drug accumulation in the meat, but also for their beneficial effects on the gut microbiota or for their immunomodulatory properties, resulting in improved production performances (Sugiharto, 2014).

Artemisinin, the main bioactive compound of the herb A. апnиa and a powerful antimalarial drug, has been extensively studied for its effects against coccidiosis in broiler chickens. Although it has been proven that it can be used as an alternative in coccidiosis control, its effects on chicken health are not well known.

In the present study, at the lowest concentration, artemisinin improved weight gain and the feed conversion ratio and the chickens had a higher feed intake. The chickens treated with $50 \mathrm{ppm}$ artemisinin had similar weight gains and feed conversion ratios as the chickens from the control group, which were fed with standard feed. However, artemisinin at the 500-ppm concentration caused reduced weight gain, inefficient feed conversion, and a lower feed intake. These negative effects are likely due to the higher quantity of the compound, which may give the feed a bitter taste and reduce its palatability, similar to what happens in children treated for malaria with artemisinin-based combination therapies (Yeka and Harris, 2010). In a singleoral dose study, Arab et al. (2009) administered 10, 50, 250,1250 , and $2500 \mathrm{mg}$ artemisinin/kg feed to 30-day-old chickens and noticed the same dose-dependent reduction in food intake. In contrast, Shahbazfar et al. (2011) did not report any negative effects on the weight gain or food intake, but they used lower doses of $17,34,68$, and $136 \mathrm{ppm}$ for 36 days. In this study, the tendency for a decreased number of erythrocytes, haemoglobin concentration, and PCV in the chickens supplemented with $500 \mathrm{ppm}$ artemisinin suggests the evolution of anaemia. Based on the increased values of $\mathrm{MCV}$, we can conclude that it is a macrocytic anaemia (Aslinia et al., 2006). Shahbazfar et al. (2011) noticed the clinical signs of anaemia in chickens fed 68 and $136 \mathrm{ppm}$ artemisinin, including a significant reduction of the haematocrit in blood tests and of the RBC count, especially at higher concentrations of artemisinin.

In the present study, the white blood cells followed a decreasing trend in all chickens that were fed the artemisinin diets, which corresponded with lymphopenia, monocytosis, and eosinopenia in the chickens supplemented with $50 \mathrm{ppm}$ and $500 \mathrm{ppm}$ artemisinin. This leukogram pattern is consistent with a stress leukogram due to endogenous steroid release in stressful conditions (Maxwell, 1993, Schmidt, 2015). This result may imply that dietary supplementation with a higher concentration of artemisinin is a stressor to the chickens.

In animal experiments, artemisinin and its derivatives have frequently produced the inhibition of erythropoiesis and this seems to represent a sensitive target for artemisinins (Efferth and Kaina, 2010). In the present study, there were sufficient numbers of erythroid precursors detected during the bone marrow evaluation for all experimental groups. Contradictory studies show that artemisinins can enhance or inhibit leukocyte functions in human or animal trials (Efferth and Kaina, 2010).

\section{Conclusions}

Artemisinin improves the productive performance of broiler chickens and has no serious side effects; thus, at $5 \mathrm{ppm}$ concentration, it is suitable for use as a feed additive in the poultry industry, in particular for organic broilers.

\section{Acknowledgments}

This study was supported by Romanian National Authority for Scientific Research, CNDI-UEFISCDI, project number $110 / 2012$.

\section{References}

Abbas, R. Z.; Colwell, D. and Gilleard, J. 2012a. Botanicals: an alternative approach for the control of avian coccidiosis. World's Poultry Science Journal 68:203-215.

Abbas, R. Z.; Iqbal, Z.; Khan, A.; Sindhu, Z. U. D.; Khan, J. A.; Khan, M. N. and Raza, A. 2012b. Options for integrated strategies for the control of avian coccidiosis. International Journal of Agriculture and Biology 14:1014-1020.

Allen, P. C.; Danforth, H. D. and Augustine, P. C. 1998. Dietary modulation of avian coccidiosis. International Journal of Parasitology 28:1131-1140.

Allen, P. C. and Fetterer, R. H. 2002. Recent advances in biology and immunobiology of Eimeria species and in diagnosis and control of infection with these coccidian parasites of poultry. Clinical Microbiology Reviews 15:58-65.

Allen, P. C.; Lydon, J. and Danforth, H. D. 1997. Effects of components of Artemisia annua on coccidia infections in chickens. Poultry Science 76:1156-1163

Alvarenga, R. R.; Rodrigues, P. B.; Zangeronimo, M. G.; Oliveira, E. C.; Mariano, F. C. M. Q.; Lima, E. M. C.; Garcia Jr, A. A. P.; Naves, L. P. and Nardelli, N. B. S. 2015. Validation of prediction equations of energy values of a single ingredient or their combinations in male broilers. Asian-Australasian Journal of Animal Sciences 28:1335-1344

Arab, H. A.; Mardjanmehr, S. H.; Shahbazfar, A.; Rassouli, A.; Abdollahi, M. and Nekouie, O. 2009. Toxicopathologic effects of artemisinin in broiler chickens following a single oral dose: An LD50 study. International Journal of Poultry Science 8:808-812. 
Arab, H. A.; Rahbari, S.; Rassouli, A.; Moslemi, M. H. and Khosravirad, F. 2006. Determination of artemisinin in Artemisia sieberi and anticoccidial effects of the plant extract in broiler chickens. Tropical Animal Health and Production 38:497-503.

Aslinia F.; Mazza J. J. and Yale S. H. 2006. Megaloblastic anemia and other causes of macrocytosis. Clinical Medicine \& Research 4:236-241.

Campbell, T. W. 1994. Hematology. p.176-197. In: Avian medicine: principles and application. Ritchie, B. W.; Harrison, G. J. and Harrison, L. R., eds. Wingers Publishing, Lake Worth, FL.

Chapman, H. D. 1997. Biochemical, genetic and applied aspects of drug resistance in Eimeria parasites of the fowl. Avian Pathology 26:221-244.

de Almeida, G. F.; Horsted, K.; Thamsborg, S. M.; Kyvsgaard, N. C.; Ferreira, J. F. and Hermansen, J. E. 2012. Use of Artemisia annua as a natural coccidiostat in free-range broilers and its effects on infection dynamics and performance. Veterinary Parasitology 186:178-187.

del Cacho, E.; Gallego, M.; Francesch, M.; Quílez, J. and SánchezAcedo, C. 2010. Effect of artemisinin on oocyst wall formation and sporulation during Eimeria tenella infection. Parasitology International 59:506-511.

Drăgan, L.; Györke, A.; Ferreira, J. F.; Pop, I. A.; Dunca, I.; Drăgan, M.; Mircean, V.; Dan, I. and Cozma, V. 2014. Effects of Artemisia annua and Foeniculum vulgare on chickens highly infected with Eimeria tenella (phylum Apicomplexa). Acta Veterinaria Scandinavica 56:22.

Efferth, T. and Kaina, B. 2010. Toxicity of the antimalarial artemisinin and its derivatives. Critical Reviews in Toxicology 40:405-21.

Elmore, S. A. 2006. Enhanced histopathology of the bone marrow. Toxicologic Pathology 3:666-686.

Maxwell, M. H. 1993. Avian blood leucocyte responses to stress. World Poultry Science Journal 49:34-43.

Naeem, M.; Idrees, M.; Singh, M.; Khan, M. M. A. and Moinuddin. 2014. Artemisia annua: A Miraculous Herb to Cure Malaria. p.27-49. In: Artemisia annua - Pharmacology and Biotechnology. Aftab, T.; Ferreira, J. F. S.; Khan, M. M. A. and Naeem, M., eds. Springer-Verlag Berlin Heidelberg.

Ognean, L. and Cernea, L. C. 2011. Practical applications in animal physiology. Ed. AcademicPres, Cluj-Napoca.
Pop, L.; Györke, A.; Tăbăran, A. F; Dumitrache, M. O.; Kalmár, Z.; Magdaş, C.; Mircean, V.; Zagon, D.; Balea, A. and Cozma, V. 2015. Effects of artemisinin in broiler chickens challenged with Eimeria acervulina, E. maxima and E. tenella in battery trials. Veterinary Parasitology 214:264-271.

Prophet, E. B.; Mills, B.; Arrington, J. B. and Sobin, L. H. 1992. Laboratory methods in histotechnology. Armed Forces Institute of Pathology-American Registry of Pathology, Washington, DC. p.53-58, 128-130, 134-136, 156-158, 170, 177-178.

Reagan, W. J.; Irizarry-Rovira, A.; Poitout-Belissent, F.; Bolliger, A. P.; Ramaiah, S. K.; Travlos, G. and Walter, G. 2011. Best practices for evaluation of bone marrow in nonclinical toxicity studies. Veterinary Clinical Pathology 40:119-134.

Sadiq, A.; Hayat, M. Q. and Ashraf, M. 2014. Ethnopharmacology of Artemisia annua L.: A review. p.9-25. In: Artemisia annua Pharmacology and biotechnology. Aftab, T.; Ferreira, J. F. S.; Khan M. M. A.; Naeem, M., eds. Springer-Verlag Berlin Heidelberg.

Samour, J. 2006. Diagnostic value of hematology. p.587-609. In: Clinical Avian Medicine. v.2. Harrison, G. and Lightfoot, T., eds. Spix Publishing, Palm Beach, FL, USA.

Schmidt S. 2015. Top 5 Leukogram Patterns. Available at: <http:// www.cliniciansbrief.com>. Accessed on: July 22, 2015.

Shahbazfar, A. A.; Mardjanmehr, S. H.; Arab, H. A.; Rassouli, A. and Abdollahi, M. 2011. Effects of artemisinin in broiler chickens following chronic oral intake. Tropical Animal Health and Production 43:843-849.

Sugiharto, S. 2014. Role of nutraceuticals in gut health and growth performance of poultry. Journal of the Saudi Society of Agricultural Sciences. doi: http://dx.doi.org/10.1016/j.jssas.2014.06.001.

Wakenell, P. S. 2010. Hematology of chickens and turkeys. p.958-966. In: Schalm's veterinary hematology. Weiss, D. J. and Wardrop, K. J., eds. Blackwell Publishing Company, USA.

Yeka, A. and Harris, J. C. 2010. Treating uncomplicated malaria in children: comparing artemisinin-based combination therapies. Current Opinion in Pediatrics 22:798-803.

Youn, H. J. and Noh, J. W. 2001. Screening of the anticoccidial effects of herb extracts against Eimeria tenella. Veterinary Parasitology 96:257-263. 